\title{
Penyuluhan Hukum Pemungutan Pajak Penghasilan (PPh) Usaha Mikro Kecil dan Menengah di Kecamatan Semarang Selatan
}

\author{
${ }^{1}$ Amin Purnawan*, ${ }^{2}$ Akhmad Khisni, ${ }^{3}$ Siti Ummu Adillah \\ $1{ }^{2}$ Prodi Magister Kenotariatan, Fakultas Hukum, UNISSULA, Semarang, Indonesia \\ ${ }^{3}$ Prodi Ilmu Hukum, Fakultas Hukum, UNISSULA, Semarang, Indonesia \\ *Corresponding Author \\ Jl. Raya Kaligawe KM. 4 Semarang, Jawa Tengah, Indonesia \\ Telp. (+6224) 6583584, Fax (+6224) 6582455 \\ Email: amin.p@unissula.ac.id.
}

\begin{abstract}
Community service in the form of legal counseling on the implementation of UMKM income tax collection in Semarang City is important, because it is expected to increase knowledge and awareness of the tax law of MSME actors. Taxation aspects that pay attention to the interests of the business world (business friendly) need to be used as a new paradigm. With globalization and structural change policies, MSMEs are increasingly needed. The role of the state is to provide an effective regulatory framework along with monitoring and enforcement mechanisms.This background of community service is based on the fact that the level of compliance of Micro, Small and Medium Enterprises (MSMEs) in fulfilling tax obligations is still very low. The contribution of UMKM to tax revenue is very small, which is approximately $0.5 \%$ of total tax revenue. UMKM is an economic sector that has a big enough role in the national economy. Based on data on Gross Domestic Product (GDP) in 2017, MSMEs have contributed approximately 57\% of total GDP. However, when compared to the contribution of MSMEs to tax revenue, there is a miss-match. Community service activities in collaboration with South Semarang District, Semarang City. Partners have a strong enough role in mobilizing MSME actors in their region. The solution offered is the formation of a tax conscious cadre group as a model and providing socialization and assistance in paying income tax for MSME players. The agreed outcome solution, namely increased knowledge and understanding of MSME income tax payments, and willingness to pay MSME tax obligations. The resulting output, namely UMKM tax conscious cadres, can conduct socialization and assistance to become obedient and voluntary UMKM taxpayers.
\end{abstract}

Keywords: Collection, Income Tax, UMKM

\begin{abstract}
Abstrak
Pengabdian masyarakat berupa penyuluhan hukum pelaksanaan pemungutan pajak penghasilan UMKM di Kota Semarang ini penting, karena diharapkan dapat meningkatkan pengetahuan dan kesadaran hukum pajak para pelaku UMKM. Aspek perpajakan yang memperhatikan kepentingan dunia usaha (business friendly) perlu dijadikan paradigma baru. Dengan adanya globalisasi dan kebijakan perubahan struktural, UMKM semakin diperlukan. Peran negara adalah menyediakan kerangka regulasi yang efektif beserta mekanisme pengawasan dan penegakan. Latar belakang pengabdian masyarakat ini didasarkan pada kenyataan tentang tingkat ketaatan Usaha Mikro, Kecil, dan Menengah (UMKM) dalam memenuhi kewajiban perpajakan masih sangat rendah. Kontribusi UMKM terhadap penerimaan pajak sangat kecil, yaitu kurang lebih $0.5 \%$ dari total penerimaan pajak. UMKM merupakan sektor ekonomi yang mempunyai peran cukup besar dalam perekenomian nasional. Berdasarkan data Produksi Domestik Bruto (PDB) tahun 2017, UMKM mempunyai kontribusi kurang lebih 57\% total PDB. Namun demikian apabila dibandingkan dengan kontribusi UMKM terhadap penerimaan pajak, terdapat miss-match. Kegiatan pengabdian masyarakat bekerja sama dengan Kecamatan
\end{abstract}


Semarang Selatan Kota Semarang. Mitra memiliki peran yang cukup kuat dalam menggerakkan pelaku UMKM di wilayahnya. Solusi yang ditawarkan adalah pembentukan kelompok kader sadar pajak sebagai model dan memberikan sosialisasi dan pendampingan pembayaran pajak penghasilan bagi pelaku UMKM. Solusi hasil yang disepakati, yaitu meningkatnya pengetahuan dan pemahaman tentang pembayaran pajak penghasilan UMKM., serta kemauan untuk membayar kewajiban pajak UMKM. Luaran yang dihasilkan, yaitu kader sadar pajak UMKM, dapat melakukan sosialisasi dan pendampingan untuk menjadi wajib pajak UMKM yang patuh dan sukarela.

Kata Kunci: Pemungutan, Pajak Penghasilan, UMKM

\section{PENDAHULUAN}

Penyuluhan hukum tentang Pelaksanaan Pemungutan Pajak Penghasilan (PPh) UMKM di Kecamatan Semarang Selatan, dilakukan dengan tujuan untuk meningkatkan kesadaran hukum pelaku UMKM agar melaksanakan kewajiban perpajakannya. Aspek perpajakan yang memperhatikan kepentingan dunia usaha (business friendly) perlu dijadikan paradigma baru, apalagi di era revolusi industri 4.0 ini, kehadiran UMKM semakin diperlukan. Peran negara adalah menyediakan kerangka regulasi yang efektif beserta mekanisme pengawasan dan penegakan hukum. Pemerintah harus mempertimbangkan kenyataan bahwa dukungan aspek legalitas tersebut sangat dibutuhkan bagi pelaku UMKM dimana pekerja berpendapatan rendah berada didalamnya. Hasil penelitian Purnawan (2019), menunjukkan bahwa problematika pelaksanaan pemungutan pajak UMKM di Kota Semarang, terutama karena kurangnya sosialisasi dan edukasi kepada pelaku UMKM yang mengakibatkan rendahnya tingkat kepatuhan hukum.

Latar belakang pengabdian masyarakat ini didasarkan pada kenyataan tentang tingkat ketaatan Usaha Mikro, Kecil, dan Menengah (UMKM) dalam memenuhi kewajiban perpajakan masih sangat rendah. Kontribusi UMKM terhadap penerimaan pajak sangat kecil, yaitu kurang lebih $0.5 \%$ dari total penerimaan pajak. UMKM merupakan sektor ekonomi yang mempunyai peran cukup besar dalam perekenomian nasional. Berdasarkan data Produksi Domestik Bruto (PDB) tahun 2017, UMKM mempunyai kontribusi kurang lebih 57\% total PDB. Namun demikian apabila dibandingkan dengan kontribusi UMKM terhadap penerimaan pajak, terdapat miss-match. Dalam upanya untuk mendorong pemenuhan kewajiban perpajakan secara sukarela (voluntary tax compliance) serta mendorong kontribusi penerimaan negara dari UMKM, Pemerintah telah menerbitkan Peraturan Pemerintah Nomor 23 Tahun 2018 sebagai pengganti PP Nomor 46 Tahun 2013 tentang Pajak Penghasilan atas Penghasilan dari Usaha yang Diterima atau Diperoleh Wajib Pajak yang Memiliki Peredaran Bruto Tertentu. Dalam Peraturan Pemerintah ini tarif PPh Final UMKM resmi diturunkan dari 1\% menjadi 0,5\%. Pengenaan PPh ini perlu dianalisis dampaknya terhadap kinerja dan kepatuhan UMKM.

Pertimbangan Pemerintah atas pengenaan PPh dengan tarif 1 persen dari peredaran usaha setiap bulan dan bersifat final terhadap UMKM sebagaimana tercantum dalam penjelasan umum PP 46 Tahun 2013 adalah kesederhanaan dalam pemungutan pajak, berkurangnya beban administrasi baik bagi Wajib Pajak maupun Direktorat Jenderal Pajak, serta memperhatikan perkembangan ekonomi dan moneter. Tidak terdapat aspek keadilan yang menjadi faktor pertimbangan terbitnya PP ini. Pengenaan PPh yang bersifat final bermakna bahwa setelah pelunasan PPh 1 persen yang dihitung dari peredaran bruto setiap bulan, kewajiban pajak atas penghasilan tersebut telah dianggap selesai dan final (Tambunan, 2013). Ditinjau dari konsep keadilan dalam pemajakan (equity principle), pengenaan PPh Final tidak sesuai dengan keadilan 
karena tidak mencerminkan kemampuan membayar (ability to pay) (Musgrave \& Musgrave, 1976 dalam Tambunan, 2013).

Pengabdian masyarakat ini akan memfokuskan pada penyuluhan hukum pelaksanaan pemungutan pajak penghasilan UMKM di Kota Semarang. Melakukan penyuluhan hukum dan edukasi pelaksanaan pemungutan pajak penghasilan UMKM. Disamping itu mengidentifikasi hambatan dalam pelaksanaan pemungutan pajak UMKM. Meningkatkan kesadaran hukum, kepatuhan dan pengetahuan serta persepsi pelaku UMKM terhadap kewajiban perpajakan. Mendapatkan luaran berupa publikasi dari hasil pengabdian ke dalam jurnal pengabdian masyarakat. Penelitian pendahuluan yang dilakukan Amin dan Adillah (2014) tentang pengembangan desain tax policy daerah berbasis keadilan untuk mendorong pertumbuhan UKM di Jawa Tengah menyimpulkan bahwa ketaatan pelaku UMKM untuk memenuhi aspek legal adalah hal yang strategis dalam menentukan keberhasilan usahanya.

Berdasarkan penelitian Heru (2014), UMKM di Indonesia merupakan salah satu pilar dalam perekonomian yang memiliki daya tahan terhadap gejolak ekonomi serta memiliki banyak bidang usaha yang dapat dikembangkan. Di sisi lain, terdapat beberapa kelemahan yang menjadi kendala pengembangan UMKM selain modal adalah modal intelektual (intellectual capital), kapabilitas manajemen, kapabilitas inovasi, entrepreneurship, produksi dan operasi, pemasaran termasuk customer relationship management dan legal. Hukum dapat berfungsi sebagai alat rekayasa sosial (law is a tool of social engineering) (Wacks, 2009). Maka melalui politik hukum legalitas usaha, UMKM dapat didorong pertumbuhannya, dan apabila dikelola dengan baik, UMKM dapat meningkatkan produktivitas, meningkatkan income masyarakat dan menyumbang bagi pendapatan daerah. Sekalipun UMKM kontribusinya sangat besar dalam menopang ekonomi nasional namun tidak serta merta diikuti peningkatan pendapatan.

Hasil yang diharapkan dari pengabdian masyarakat ini adalah meningkatnya kesadaran hukum UMKM untuk mengurus NPWP dan membayar kewajiban pajaknya. Pengabdian ini juga bertujuan ikut mengembangkan usaha mikro kecil khususnya di Kota Semarang terutama dari aspek pajak, disamping itu perlu peningkatan sumber daya manusia, pemasaran, keuangan produksi, inovasi dan teknologi, ICT agar mampu menghasilkan kinerja yang optimal dan mampu memiliki daya saing baik lokal, nasional maupun internasional. Dengan adanya UMKM yang berkinerja tinggi, menurut Manurung (2008), maka akan mendorong peningkatan ekonomi masyarakat, meningkatkan lapangan kerja serta mengurangi tingkat kemiskinan. Kelengkapan aspek legalitas usaha UMKM sangat penting dalam menciptakan kepastian hukum yang dapat mendukung kinerja dan keunggulan bersaing yang berkelanjutan khususnya usaha mikro kecil dan menengah. Hasil penelitian Heru (2014) bahwa keberhasilan dalam mengelola aspek legalitas, organizational knowledge assets, customer relationship management, dan innovation capability akan memberikan dampak pada keunggulan bersaing UMKM dan mampu memberikan kontribusi PDRB Jawa Tengah.

\section{METODE PELAKSANAAN}

Pemecahan permasalahan pemungutan PPh UMKM di Kecamatan Semarang Selatan dalam meningkatkan pemahaman pentingnya aspek pajak dan bagaimana tata cara pengurusannya dilakukan dengan beberapa pendekatan yang dilakukan secara bersama-sama, yaitu: 1) Ceramah dan tutorial, metode ini dilakukan pada kegiatan pelatihan dan pendampingan. Tim pelaksana pengabdian memberikan materi dengan metode ceramah disertai dengan tanya jawab serta tutorial untuk membantu peserta pengabdian. 2) Berbasis small group discussion, yaitu metode small group discussion adalah suatu cara mengajar yang dibagi 
menjadi beberapa kelompok. Setiap kelompok dibagi menjadi tiga sampai dengan lima orang (Fatimah, S., dkk., 2012). Mereka bekerja sama dalam memecahkan masalah atau mempersiapkan syarat-syarat yang harus dilengkapi untuk memperoleh IUMK., setelah diadakan pelatihan dan pendampingan. Maka ada kegiatan semacam diskusi kecil sebagai follow up dari pelatihan sebelumnya. 3) Komprehensif, seluruh kegiatan pengabdian masyarakat dilakukan secara serentak terkait dengan Sumber Daya manusia (SDM), proses belajar, pelatihan dan pendampingan tenaga pengajar dan dibantu aparat kecamatan yang professional, 4) Learning by doing berbasis output. Hasil pengabdian yang dilakukan dengan proses pendampingan diharuskan menghasilkan terbitnya Nomor Pokok Wajib Pajak (NPWP) untuk masing-masing peserta penyuluhan yang belum memilikinya. Selanjutnya, ketiga metode di atas diimplementasikan dalam empat tahapan, yaitu sosialisasi, peningkatan kompetensi, pendaftaran atau pelaksanaan kegiatan, serta monitoring dan evaluasi. Pelaksanaan kegiatan pengabdian dilakukan dalam bulan Januari 2021. Mitra adalah pelaku UMKM Kecamatan Semarang Selatan. Adapun tahap-tahap yang kami lakukan pada pengabdian ini meliputi:

a. Observasi Kegiatan PKM

Pada tahap awal kegiatan pengabdian kami melakukan observasi awal sebagai bahan pengabdian kami. Selain observasi kami melakukan wawancara dan audensi kepada Camat Semarang Selatan. Dari hasil observasi yang kami lakukan diperoleh data bahwa UMKM di Kecamatan Semarang Selatan sebagian besar masih belum memiliki NPWP. Kemudian disepakati untuk mengadakan penyuluhan hukum dan pendampingan dengan peserta perwakilan dari 10 kelurahan yang ada.

b. Penyuluhan Hukum dan Pendampingan

Berdasarkan permasalahan yang ada maka pengabdian kami lakukan dengan beberapa kegiatan, salah satunya adalah penyuluhan hukum dan pendampingan. Penyuluhan hukum menggunakan metode ceramah dan tanya jawab. Pada acara pembukaan juga disampaikan sambutan Kasi Kesejahteraan Sosial Kecamatan Semarang Selatan yang mengapresiasi kegiatan penyuluhan ini karena dapat mendorong kemajuan usaha dan daya saing UMKM.

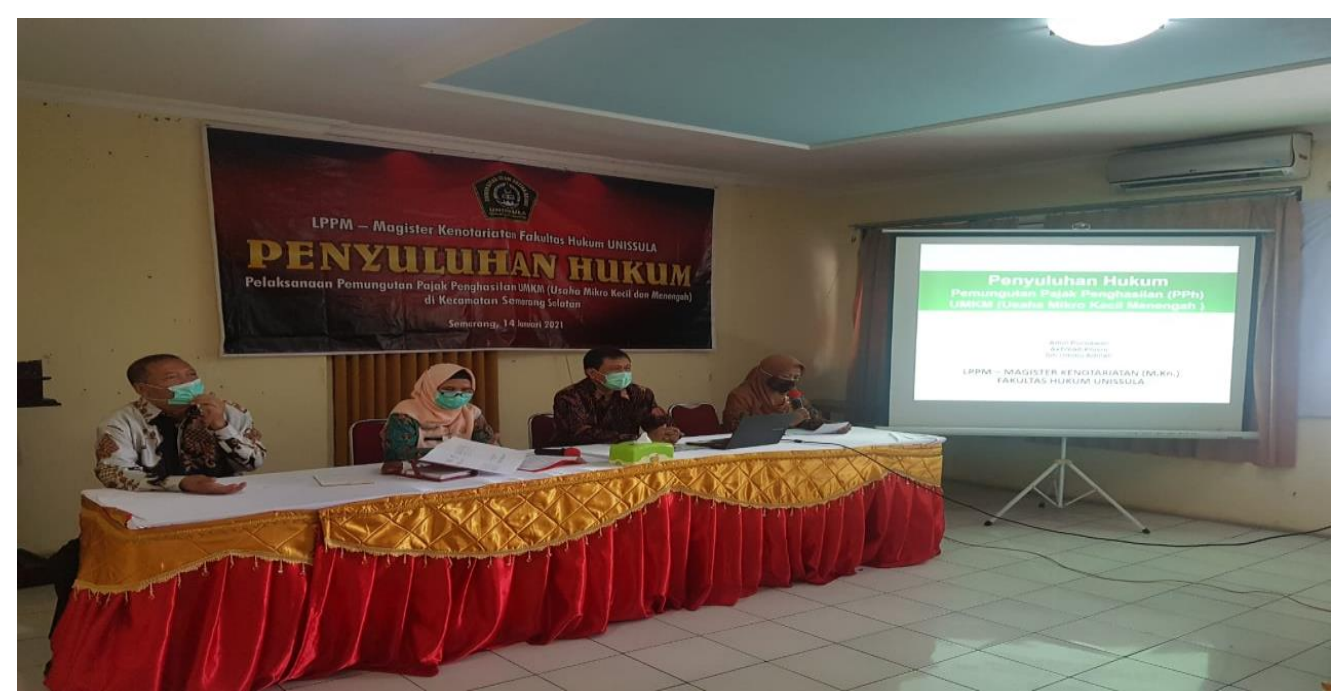

Gambar 1. Penyampaian materi penyuluhan hukum oleh Tim Penyuluhan Hukum Magister Kenotariatan FH Unissula, bertempat di Aula Kecamatan Semarang Selatan, 14 Januari 2021 


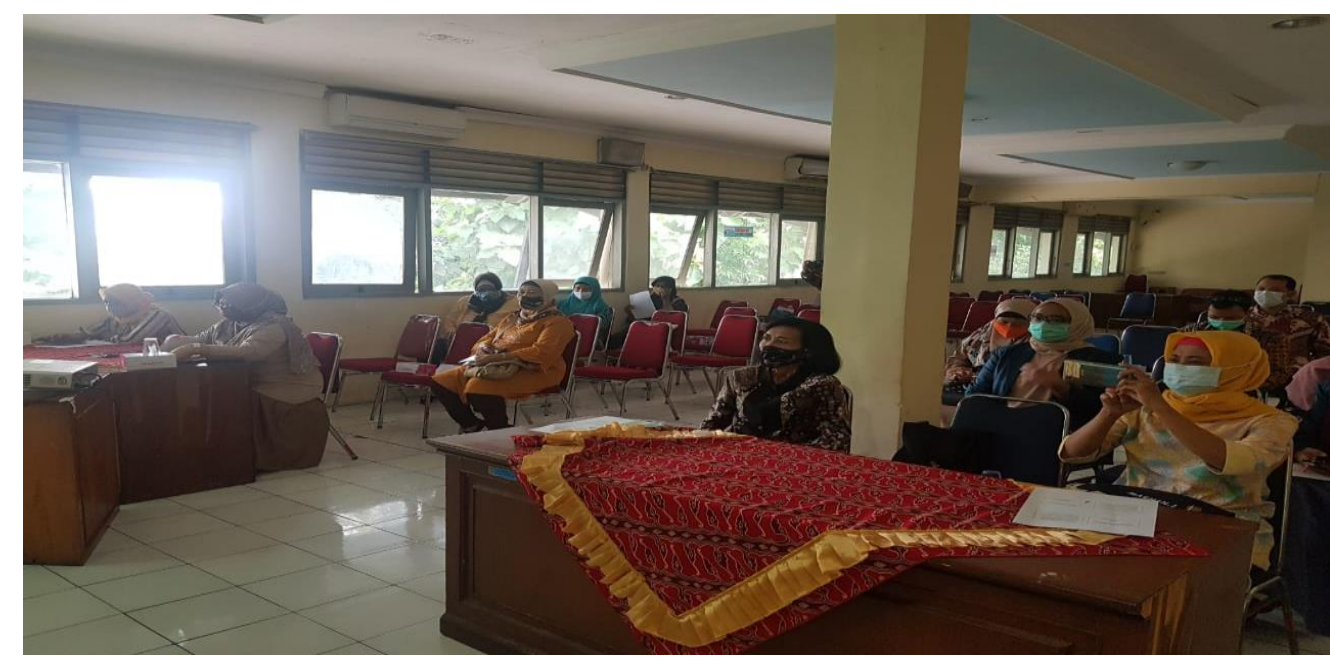

Gambar 2. Peserta penyuluhan hukum dari pelaku UMKM Kecamatan Semarang Selatan sangat antusias mengikuti penyampaian materi penyuluhan hukum tentang Pemungutan PPh UMKM

\section{d. Pelaksanaan Kegiatan Pendampingan}

Pada rangkaian kegiatan pengabdian yang diadakan adalah dalam rangka memacu motivasi pelaku UMKM untuk memiliki NPWP. Dengan demikian, dari rangkaian kegiatan pengabdian kami mengadakan pendampingan dan bimbingan teknis pendaftaran NPWP yang dibantu langsung oleh petugas dari kantor kecamatan.

\section{e. Monitoring dan Evaluasi}

Tahapan akhir dari rangkaian kegiatan pengabdian masyarakat yang dilakukan adalah monitoring dan evaluasi. Selama kegiatan pengabdian masyarakat berlangsung dengan baik di aula kantor Kecamatan Semarang Selatan, berjalan dengan lancar dan memperoleh respon yang baik dari camat dan staf maupun para pelaku UMKM. Kegiatan monitoring yang kami lakukan adalah monitoring saat berlangsungnya kegiatan penyuluhan hukum, sosialisai, dan pendampingan. Hasil monitoring yang dilakukan terlihat setiap kegiatan berjalan sesuai dengan rencana. Estimasi dana dan waktu tidak banyak berubah. Materi yang disajikan tidak ada yang tertinggal. Pelaksanaan sesuai dengan tanggal yang telah disepakati pihak kecamatan dan tim pengabdian masyarakat. Pelaksanaan monitoring juga kami lakukan terhadap pendampingan pendaftaran NPWP. Kami sudah menyampaikan kepada semua peserta akan siap sedia, baik langsung maupun tidak untuk melaksanakan monitoring dan pendampingan jika ada UMKM yang berkenan. Hal ini memperoleh tanggapan yang baik dari para pelaku UMKM dan pihak kecamatan. Pendampingan yang kami lakukan sampai dengan terbitnya NPWP. Adapun evaluasi kami lakukan secara terus-menerus dan berkesinambungan. Selama pelaksanaan kegiatan kami juga menerima kritik dan masukan dari peserta.

\section{HASIL DAN PEMBAHASAN}

Dengan adanya pelaksanaan pengabdian kepada masyarakat di Kecamatan Semarang Selatan dapat memberikan banyak manfaat kepada pelaku UMKM. Pajak sebelumnya hanya dipandang sebagai tidak penting dan membebani UMKM serta merepotkan pengurusannya, namun ternyata sangat diperlukan bagi kelangsungan pembangunan nasional termasuk mereka perlukan dalam mendorong pertumbuhan dan daya saing usahanya. 
Fungsi negara dalam bidang ekonomi, menurut W. Friedman (Wacks, 2009) yaitu sebagai penjamin (provider) kesejahteraan rakyat, negara sebagai pengatur (regulator), negara sebagai pengusaha (entrepreneur) atau menjalankan sektor-sektor tertentu melalui Badan Usaha Milik Negara (BUMN), dan negara sebagai wasit (umpire) untuk merumuskan standar-standar yang adil mengenai sektor ekonomi termasuk perusahaan negara (state corporation). Pembangunan nasional merupakan proses perubahan struktural yang dilakukan secara terus menerus dan berkesinambungan. Pembangunan adalah proses natural untuk mewujudkan citacita bernegara, yaitu masyarakat makmur sejahtera, adil, dan merata. Proses natural tersebut dapat terlaksana jika asumsi-asumsi pembangunan dapat dipenuhi, yaitu kesempatan kerja atau partisipasi termanfaatkan secara penuh (full employment), setiap orang memiliki kemampuan yang sama (equal productivity, equal access, level playing field), dan masing-masing pelaku bertindak rasional (efficient).(Sumodiningrat, 2001)

Michel Todaro (1994) berpendapat, pembangunan adalah proses multidimiensional yang melibatkan perubahan-perubahan mendasar dalam struktur sosial, perilaku sosial, dan institusi nasional. Di samping itu, akselerasi pertumbuhan ekonomi, pengurangan ketidakmerataan, dan pemberantasan kemiskinan juga diagendakan. Kemiskinan merupakan masalah kronis yang melanda bangsa Indonesia. Berdasarkan laporan Microcredit Summit tahun 2002 (Amalia, 2009), jumlah penduduk dunia yang hidup di bawah garis kemiskinan diperkirakan sekitar 235 juta keluarga, sebagian diantaranya yaitu 157,8 juta (67\%) ada di negara-negara Asia. Salah satu upaya penanggulangan kemiskinan adalah dengan memutus mata rantai kemiskinan melalui pemberdayaan kelompok masyarakat yang memiliki usaha pada sektor paling kecil (UMKM). Dengan adanya pelaksanaan pengabdian kepada masyarakat di Kecamatan Semarang Selatan dapat memberikan banyak manfaat kepada pelaku usaha UMKM. Pajak sebelumnya hanya dipandang sebagai membebani mereka baik dalam hal pengurusan pendaftarannya, biaya, maupun aspek manfaatnya. Namun, ternyata setelah diberikan penjelasan mengenai pentingnya pajak bagi pembangunan, serta pelaksanaan pendaftaran yang sangat mudah, cepat, dan tanpa dipungut biaya, disamping manfaat yang akan diperoleh dengan dimilikinya NPWP, mereka menjadi sangat antusias untuk mengurus dan melaksanakan kewajiban pajaknya. Penyuluhan hukum ini menjadi lebih hidup karena mereka dapat saling berinteraksi membuat jejaring, dan tukar pengalaman dalam menjalankan usahanya. Maka, pengabdian masyarakat ini memiliki sasaran yang tepat yaitu dengan mendorong UMKM memiliki NPWP dengan harapan usahanya akan semakin maju dan berkembang.

\section{SIMPULAN}

Pengabdian masyarakat tentang Pelaksanaan Pemungutan PPh UMKM di Kecamatan Semarang Selatan ini telah dapat mendorong kesadaran dan kepatuhan hukum pelaku usaha UMKM untuk memiliki NPWP. Mereka menjadi sadar bahwa pembayaran pajak sangat penting bagi pembangunan dan dana pajak juga akan meningkatkan pertumbuhan dan daya saing UMKM. Aspek perpajakan yang memperhatikan kepentingan dunia usaha (business friendly) perlu dijadikan paradigma baru.

\section{SARAN}

Disamping itu, sosialisasi dan edukasi kepada pelaku usaha UMKM terkait kewajiban perpajakannya perlu lebih ditingkatkan. Karena kegiatan penyuluhan dan pendampingan tersebut ternyata dapat mempengaruhi kepatuhan UMKM untuk mengurus membayar pajaknya. 


\section{UCAPAN TERIMA KASIH}

Tim pelaksana pengabdian mengucapkan terima kasih kepada Camat Semarang Selatan dan pelaku UMKM yang telah menjadi mitra dalam pelaksanaan pengabdian ini, Lembaga Penelitian dan Pengabdian Masyarakat (LPPM) UNISSULA, Dekan FH UNISSULA serta pihak terkait lain yang telah membantu selama kegiatan.

\section{DAFTAR PUSTAKA}

Adler Haymans Manurung. (2008). Modal untuk Bisnis UKM. Jakarta: Gramedia.

Amin Purnawan. (2011). "Rekonstruksi Sistem Pemungutan Pajak Penghasilan (PPh) Badan Berbasis Nilai Keadilan" dalam Jurnal Dinamika Hukum Terakreditasi, ISSN 14100797, Vol. 11 Edisi Khusus Februari.

Amin Purnawan, Siti Ummu Adillah. (2014). "Pengembangan Desain Tax Policy Daerah Berbasis Keadilan untuk Mendorong Pertumbuhan Usaha Kecil Menengah (UKM) di Jawa Tengah" Penelitian Hibah Unggulan Perguruan Tinggi. Semarang: Fakultas Hukum Unissula.

Amin Purnawan. (2020). Problematika Pelaksanaan Pemungutan Pajak Penghasilan (PPh) UMKM di Kecamatan Semarang Selatan. Laporan Penelitian Internal LPPM Unissula, Semarang: Fakultas Hukum Unissula.

Euis Amalia. (2009). Keadilan Distributif dalam Ekonomi Islam Penguatan Peran LKM dan UKM di Indonesia, Jakarta: RajaGrafindo Persada

Fatimah, S., dkk. (2012). Pembelajaran fisika menggunakan model cooperative learning ditinjau dari prestasi belajar siswa. Jurnal Kependidikan: Penelitian Inovasi Pembelajaran, 42(1).Fatimah, S., Kartika, I., \& Niyartama, T. F. (2012). Pembelajaran fisika menggunakan model cooperative learning ditinjau dari prestasi belajar siswa. Jurnal Kependidikan: Penelitian Inovasi Pembelajaran, 42(1).

Gunawan Sumodiningrat. (2001). "Kepemimpinan dan Pemberdayaan Ekonomi Rakyat". Naskah Pidato Pidato Pengukuhan Jabatan Guru Besar pada Fakultas Ekonomi Universitas Gadjah Mada 17 Maret 2001. Yogyakarta: UGM

Heru, Wuryanti, Siyamtinah. (2014). Keunggulan Bersaing UMKM tenun Jawa Tengah berbasis organizational knowledge assets \& CRM. Laporan Penelitan Hibah Dikti. Semarang: FE Unissula

Michael Todaro. (1994). Economic Development. Singapore: Longman Singapore Publisher

Raymond Wacks, 2009, Understanding Jurisprudence An Introduction to Legal Theory, Oxford University Press, New York

\section{Peraturan Perundang-undangan}

Undang-undang Nomor 20 Tahun 2008 tentang Usaha Mikro, Kecil dan Menengah.

Peraturan Pemerintah Nomor 17 Tahun 2013 tentang Pelaksanaan Undang-undang Nomor 20 Tahun 2008 tentang Usaha Mikro, Kecil dan Menengah

Peraturan Menteri Dalam Negeri No.83 Tahun 2014 tentang Pedoman Pemberian Izin Usaha Mikro dan Kecil

Peraturan Daerah Provinsi Jawa Tengah Nomor 13 Tahun 2013 tentang Pemberdayaan Usaha Mikro, Kecil, dan Menengah. 